\title{
Epidemiologi av urinsyregikt
}

\author{
Johan F. Skomsvoll ${ }^{1,2}$ og Erik Rødevand ${ }^{1}$ \\ 1) Klinikk for ortopedi og revmatologi, Revmatologisk avdeling, St. Olavs hospital \\ 2) Institutt for nevromedisin, Norges teknisk-naturvitenskapelige universitet (NTNU)
}

\section{ENGLISH SUMMARY}

Skomsvoll JF, Rødevand E. The epidemiology of gout. Nor J Epidemiol 2008; 18 (1): 23-29.

Gout is more prevalent in men than in women. However, there is a reduction in the difference in prevalence between men and women after menopause. The incidence is low in young age, but increases with increasing age, particularly after the age of 50 . The risk of gout attack is to some extent dependent on the level of the serum concentration of urate. In the last decades the prevalence of gout has increased substantially, probably due to increase in the proportion of people with overweigth, disease promoting lifestyle changes, metabolic syndrome, diabetes and cardiovascular disease (CVD). Hypeuricemia inducing drugs may also play a role. Drugs may play an important role in the treatment of the acute gout attacks. However, changes in lifestyle and diet are important prophylactic efforts. High levels of serum urate may be a risk factor for the development of CVD, but at the moment it is not explored whether the serum urate level is a marker or an independent contributor to the morbidity and mortality of CVD.

\section{HISTORIEN}

Urinsyregikt har vært kjent fra antikken og er beskrevet av Hippocrates. Sykdommen ble tidligere betraktet som en sykdom blant rike middelaldrende menn, ofte historisk kjente personer som konger, kunstnere, statsog vitenskapsmenn. Mennesket er det eneste pattedyret hvor urinsyregikt utvikler seg spontant, fordi det mangler enzymet uricase som konverterer urinsyre til allantoin. De fleste dyr har derfor et lavt urinsyrenivå, mens mennesket har et høyere nivå på ca. 386-416 mikromol/L. Dette fører til at serumurinsyrenivået, som er endeproduktet i purinmetabolismen raskere når sin fysiologiske grense for løselighet. Overskrides denne grensen, dannes det uratkrystaller. Krystalliseringen finner hyppigst sted i ledd, sener og bursae, men kan forekomme i de fleste vev og organer. Urinsyregikt affiserer minst $1 \%$ av populasjonen $\mathrm{i}$ vestlige land. Hyppigheten antas å være økende og er trolig den vanligste årsaken til inflammatorisk leddsykdom hos menn eldre enn 40 år (1).

\section{DIAGNOSTISKE KRITERIER}

Sikker diagnose krever påvisning av uratkrystaller i leddvæske under et anfall eller i en tofus (2). I større populasjonsstudier er det vanskelig å bruke dette kriteriet og ulike kriteriesett (Romakriterier, New York kriterier, ACR kriterier) er derfor utviklet og har vært benyttet (Tabell 1-3) (3-5). I fravær av påviste uratkrystaller i leddvæske eller i tofi, kan kriteriene listet i tabell 1 benyttes for å sannsynliggjøre diagnosen akutt urinsyregikt (2). Seks eller flere kriterier fra listen på 12 kriterier ble funnet i $87,6 \%$ av pasientene med urinsyregikt og i $10,9 \%$ av pasientene med kalsium pyrofosfat artritt. Ved samtidig påvisning av krystaller $ø$ ker sensitiviteten til $97,8 \%$ for pasienter med urin-
Tabell 1. Foreslåtte diagnosekriterier for akutt primær urinsyregikt (ACR).

\begin{aligned} & \hline $\begin{array}{l}\text { Kriterie } \\ \mathrm{nr}\end{array}$ Utfallskriterium \\ & \hline 1 Mer enn et anfall av akutt artritt \\ & 2 Maks inflammasjon utviklet i løpet av 1 døgn \\ & 3 Artritt i et ledd (monoartritt) \\ & 4 Rødhet rundt leddet \\ & 5 Smerter og hevelse tilsvarende første MTP ledd \\ & 6 Ensidig artritt i første MTP ledd \\ & 7 Ensidig artritt i et annet tåledd \\ & 8 Tofus (påvist eller mistenkt) \\ & 9 Hyperurikemi \\ & 10 Hevelse i et ledd på røntgenbilde* \\ & 11 Subkondral cortical cyste uten erosjon på \\ & røntgenbilde \\ & 12 $\begin{array}{l}\text { Mononatriumurat monohydrat krystaller } \\ \text { (urinsyrekrystaller) i leddvæske under anfall }\end{array} \\ & 13$ Dyrkning av leddvæske (tatt under anfall) uten \\ & oppvekst av mikrober \\ & \hline\end{aligned}

Modifisert etter referanse 3

Tabell 2. Foreslåtte kriterier for akutt primær urinsyregikt (ACR).

\begin{tabular}{cl}
\hline $\begin{array}{l}\text { Kriterie } \\
\text { nr }\end{array}$ & Utfallskriterium \\
\hline 1 & Mer enn et anfall av akutt artritt \\
2 & Maksimal inflammasjon utviklet innen 1 døgn \\
3 & Oligoartritt anfall \\
4 & Rødhet over ledd \\
5 & Smerter og hevelse over første MTP ledd \\
6 & Unilateral anfall i første MTP ledd \\
7 & Unilateralt tarsal (mellomfot) leddsanfall \\
8 & Tofus (påvist eller mistenkt) \\
9 & Hyperurikemi \\
10 & Hevelse i et ledd på røntgenbilde* \\
11 & Fullstendig tilbakegang av et anfall med artritt \\
\hline$*$ Modifisert etter referanse 3
\end{tabular}


syregikt. Det andre settet (Tabell 2) med foreslåtte kriterier økte spesifisiteten til 92,7\%, men reduserte sensitivitet. Disse kriteriene er foreslått anvendt i populasjonsstudier, men ikke for å diagnostisere individuelle pasienter.

\section{Prevalens}

\section{Nordiske land}

I en dansk intervjubasert studie fant man en prevalens av urinsyregikt på 1,6\% hos menn i alderen 40-59 år (6). Diagnosen urinsyregikt bygget på om det hadde forekommet typiske artrittanfall og om anfallet var diagnostisert og behandlet av lege. Prevalensen var sammenlignbar med det som ble funnet i Tecumseh (Michigan) (1,3\%) og New York $(2,4 \%)(7,8)$. Sammenlignet med de ikke-skandinaviske urinsyregiktstudiene hadde individene i denne, høyere vekt, diastolisk blodtrykk og alkoholforbruk. Prevalensen var høyest i de lavere sosioøkonomiske klassene.

I en svensk studie med følgende kriterier - en sykehistorie med episodisk smerte, ømhet og hevelse av ledd og/eller tilstedeværelse av tofi med hyperurikemi - ble det funnet en samlet prevalens for kvinner og menn på $1,3 \%$. Prevalensen var noe lavere for kvinner enn for menn, henholdvis $1,2 \%$ og 1,4\%. Prevalensen av hyperurikemi var $16 \%$, noe lavere hos kvinner (12\%) enn hos menn (26\%). Studien omfattet 79 åringer i Gøteborg (9). Hyperurikemi resulterte ikke i en øket prevalens av urinsyregikt i denne studien noe som er i tråd med tidligere svenske populasjonsstudier $(10,11)$.

I en norsk tverrsnittsstudie (som en del av en nasjonal helsestudie), basert på et spørreskjema og blodprøver, så man på forekomsten av muskelskjelett- symptomer i forhold til serumurinsyrenivået (12). Både menn $(\mathrm{N}=737)$ og kvinner $(\mathrm{N}=771)$ i alderen $40-42$ år med muskelskjelettsymptomer hadde et signifikant høyere serumuratnivå enn personer uten slike symptomer, men personer med kjent urinsyregikt var ekskludert. Multivariat logistisk regresjonsanalyse viste at odds ratio for kroniske muskelskjelettplager steg med økende urinsyrenivå i et dose-respons forhold (justert for 12 andre uavhengige variabler som påvirker urinsyrenivået). Resultatet er en indikasjon på at urinsyrenivået kan bidra til muskelskjelettplager, men ingen kausalitet er bevist. For øvrig kjenner man ikke til norske studier når det gjelder forekomsten av urinsyregikt.

\section{Land utenom Norden}

Resultater fra regionale amerikanske populasjonsbaserte studier basert på ulike kriterier, er presentert i tabell 3 (7,13-15). Den høyere prevalensen i Framinghamstudien skyldes en eldre populasjon sammenlignet med de to andre.

Den nasjonale prevalensen av urinsyregikt i USA er basert på selvrapporterte data $i$ flere studier som "National Health Interview Survey" (NHIS, 1996) og "Third National Health and Nutrition Examination Survey" (NHANES III, 1988-94) (16). Forskjellen på disse to studiene var at i NHIS ble respondentene spurt om de hadde hatt et urinsyregiktanfall det siste året, mens i NHANES-studien ble det spurt om en lege, men ikke annet helsepersonell (var det annet helsepersonell ble det kodet som nei) hadde sagt at de hadde urinsyregikt. Validiteten av selvrapporterte data varierer betydelig i de ulike studiene, fra $44 \%$ i Sudburystudien (15) til $80 \%$ når spørsmålene ble besvart i henhold til ACR-kriterier. Verifisering ved hjelp av journaldata/informasjon øker validiteten til 100\% (17).

Tabell 3. Prevalens av urinsyregikt - regionale amerikanske populasjonsstudier.

\begin{tabular}{|c|c|c|c|c|c|}
\hline \multirow[b]{2}{*}{ Studie (år) [Ref] } & \multirow{2}{*}{$\begin{array}{l}\text { Urinsyregikt- } \\
\text { kriterier }\end{array}$} & \multirow[b]{2}{*}{ Alder } & \multicolumn{3}{|c|}{ Prevalens (pr 1000) } \\
\hline & & & Total & Menn & Kvinner \\
\hline Tecumseh Community Health study (1960) [7] & "Roma" 1 & $\geq 20$ & & 7,2 & 4,8 \\
\hline Framingham Heart study (1964) [14] & Arbitrært $^{2}$ & $\geq 42$ (mean, 58) & 14,8 & 28,5 & 3,9 \\
\hline Sudbury Study (1972) [15] & Roma $^{3}$ og NY ${ }^{4}$ & $\geq 15$ & 3,7 & 6,6 & 1,0 \\
\hline \multicolumn{6}{|l|}{ Modifisert etter referanse 2} \\
\hline \multicolumn{6}{|c|}{$\begin{array}{l}1 \text { ”Så langt som mulig” etter Roma-kriteriene (1. forhøyet serum uratverdi, 2. tilstedeværelse av tofi, 3. påvisning av } \\
\text { uratkrystaller i leddvæke eller i vev og 4. smertefulle anfall med leddhevelser som går over innen 1-2 uker. Diagnose } \\
\text { hvis } 2 \text { kriterier er oppfylt). }\end{array}$} \\
\hline \multicolumn{6}{|c|}{${ }^{2}$ Minst to av følgende funn: et typisk artrittanfall, et anfall med artritt uten respons på kolkisin og hyperurikemi. } \\
\hline \multicolumn{6}{|l|}{${ }^{3}$ Roma: Roma-kriteriene for urinsyregikt. } \\
\hline \multicolumn{6}{|c|}{$\begin{array}{l}{ }^{4} \text { NY: New York-kriterier for urinsyregikt: Diagnose stilles enten ved påvisning av uratkrystaller i leddvæske eller i vev } \\
\text { eller ved tilstedeværelse av to eller flere kriterier: } 1 \text {. En sykehistorie og/eller observasjon på minst to anfall av } \\
\text { smertefulle leddhevelser. Det må være en rask og sterk innsettende smerte i tidlig fase og fullstendig klinisk remisjon } \\
\text { innen } 1-2 \text { uker. } 2 \text {. En historie på og/eller observasjon av artritt i et anfall som beskrevet under pkt } 1 \text { og som involverer } \\
\text { stortåa. } 3 \text {. Tilstedeværelse av klinisk påvist tofus. } 4 \text {. Informasjon om og/eller observasjon av god respons på Kolsikin, } \\
\text { definert som en betydelig reduksjon i objektive tegn på inflammasjon innen } 48 \text { timer etter start av behandling. }\end{array}$} \\
\hline
\end{tabular}


De nyeste selvrapporterte data på urinsyregikt er fra NHIS i 1996 (Tabell 4) (18). Samlet 1 års prevalens var 9,4 pr 1000 personer I USA. Prevalensen av urinsyregikt økte med alder og var høyere hos menn enn hos kvinner. Den var enda høyere hos svarte menn over 45 år enn hos hvite i samme aldersgruppe. Нøy prevalens var også knyttet til familier med lav inntekt.

I NHANES III studien bygget livstidsprevalensen for begge kjønn på spørsmålet: har en lege noen gang fortalt at du har urinsyregikt? Forekomsten var lavest $\mathrm{i}$ alderen 20-29 år (0,4\%) og høyest $i$ alderen 70-79 år (8\%) (16). Prevalensen for urinsyregikt for menn i alderen 70-79 år var 11,6\%, mens prevalensen blant kvinner var 3,2\% i alderen 60-69 år og 5,2\% i alderen 70-79 år. Nasjonale data tyder på en livstidsprevalens på $2,7 \%$ i USA. Dette estimatet bygger på selvrapporterte data, men forutsetter at diagnosen er legeverifisert. Siden det ikke er krav til hvilke kriterier for diagnosen som er benyttet, er en feil estimering mulig.

Amerikanske langtidstudier viser en markant økning i 1 års prevalensen mellom 1969 og 1976, en økning som i redusert takt har fortsatt (Tabell 5) (19). En studie fra England viser at prevalensen av urinsyregikt i 1991 var 3 ganger høyere, sammenlignet med estimatene fra 1970 tallet (20). En annen studie fra USA viste at urinsyregikt eller hyperurikemi som krevde behandling med urinsyresenkende medikasjon økte med 80\% fra 1990 til 1999 (21).

Tabell 4. Årlig prevalens av urinsyregikt pr 1000 i USA etter alder, kjønn, rase og inntekt, 1996.

\begin{tabular}{lccc}
\hline & \multicolumn{3}{c}{ Alder, år } \\
\cline { 2 - 4 } & $<45$ & $45-64$ & $>65$ \\
\hline Kjonn & 3,4 & 33,5 & 46,4 \\
Mann & 0,2 & 12,0 & 19,5 \\
Kvinne & & & \\
Rase/befolkningsgruppe & 1,9 & 21,0 & 31,0 \\
Hvite & 0,7 & 35,6 & 35,2 \\
Svarte & & & \\
Inntekt & - & 54,9 & 36,6 \\
$<\$ 10.000$ & - & 23,9 & 34,9 \\
\$10.000-\$19.999 & 1,4 & 29,8 & 21,5 \\
\$19.999-\$34.999 & 2,8 & 18,3 & 28,5 \\
$\geq \$ 35.000$ & & & \\
\hline
\end{tabular}

Modifisert etter referanse 2 .

Tabell 5. Trend i årlig prevalens av urinsyregikt (for kvinner og menn) pr 1000 i USA 1969-96 (NHIS)*.

\begin{tabular}{lcccc}
\hline & \multicolumn{4}{c}{ Aldersgruppe, år } \\
\cline { 2 - 5 } År & Alle aldre & $17 / 18-44$ & $45-64$ & $\geq 65$ \\
\hline 1969 & 4,8 & 3,1 & 12,0 & 12,7 \\
1976 & 7,8 & 3,8 & 18,4 & 24,1 \\
1988 & 8,5 & 3,1 & 21,0 & 27,0 \\
1996 & 9,4 & 1,8 & 22,4 & 30,8 \\
\hline
\end{tabular}

* 1-års prevalens av urinsyregikt estimert etter spørsmålet: "Har du eller noen i din familie hatt urinsyregikt i løpet av det siste året?" Modifisert etter referanse 2.

\section{INSIDENS}

\section{Nordiske land}

Isomäki beskriver den kumulative insidensen av urinsyregikt ved Rheumatism Foundation Hospital (Heinola, Finland) og insidens av legemiddelbehandlet urinsyregikt og/eller hyperurikemi i Finland (22). I perioden 1952-59 beskrives 2 pasienter ved sykehuset og i 1960-68 15 pasienter. I 1976 er 17 pasienter behandlet ved sykehuset, kumulativt 77 pasienter i perioden 1952-76 og for landet som helhet, er 2188 pasienter behandlet med urinsyresenkende legemiddel i samme periode. Det har således vært en betydelig økning i foreskrivning av legemiddel for urinsyregikt/ hyperurikemi de siste 8 årene. Økningen ble tidoblet fra 218 til 2188 pasienter i perioden 1952-76. Liknende tendens er observert i flere land.

\section{Land utenom Norden}

I Rochester Epidemiology Project i USA fant man en årlig alders- og kjønnsjustert insidensrate på 45,0 pr 100.000 (95\% CI 30,7-59,3) i perioden 1977-78 basert på 39 nye pasienter med urinsyregikt bedømt etter ACR-kriteriene (Tabell 6) (23). I perioden 1995-96, ble 81 pasienter diagnostisert noe som gav en årlig justert insidensrate på 62,3 pr 100.000 (95\% CI 48,476,2) (Tabell 6) (23). Tallene viser en dobling av raten for primær urinsyregikt i den mellomliggende 20 års periode uten diuretikaeksponering. Sekundær eller diuretika-assosiert urinsyregikt økte ikke (23). I Johns Hopkins Precursor studien fant man 60 tilfeller av urinsyregikt hos 1216 mannlig leger i en median oppfølgingstid på 29 år, noe som indikerte en årlig insidensrate på 1,7 pr 1000 (95\% CI 1,3-2,2) (24).

\section{RISIKOFAKTORER FOR URINSYREGIKT}

\section{Demografiske faktorer}

\section{Alder}

Insidens og prevalens øker med alderen både for menn og kvinner $(13,16,18,25)$. Dette henger trolig sammen med stigende urinsyrenivå med alder hos begge kjønn, men trenden er lavere hos kvinner enn hos menn (6).

Tabell 6. Årlig insidens av urinsyregikt pr 1000 i Rochester County.

\begin{tabular}{lcccccc}
\hline & $1977-78$ & & & $1995-96$ & \\
\cline { 2 - 3 } \cline { 5 - 6 } Alder & Menn & Kvinner & & Menn & Kvinner \\
\hline $20-29$ & 0,2 & 0,0 & & 0,1 & 0,0 \\
$30-39$ & 0,6 & 0,0 & & 0,8 & 0,1 \\
$40-49$ & 1,1 & 0,2 & & 1,0 & 0,1 \\
$50-59$ & 1,6 & 0,4 & & 1,6 & 0,0 \\
$60-69$ & 1,3 & 0,5 & & 2,5 & 0,6 \\
$70-79$ & 2,3 & 0,6 & & 4,6 & 1,3 \\
$\geq 80$ & 2,6 & 0,9 & & 3,4 & 1,6 \\
\hline
\end{tabular}

Modifisert etter referanse 2 
Aldersassosierte risikofaktorer som nedsatt nyrefunksjon, nedsatt enzymaktivitet for enzymet xantinoxidase som metaboliserer omdanningen av hypoxantin til urinsyre, og samtidig økende prevalens av kroniske sykdommer som krever bruk av legemidler, er faktorer som bidrar til den høyere forekomsten av urinsyregikt og hyperurikemi.

\section{Kjønn}

Prevalens og insidens av urinsyregikt er høyere hos menn enn hos kvinner men forskjellen blir mindre med økende alder og særlig etter menopausen. Rochesterprosjektet indikerer at insidensen av primær urinsyregikt er doblet hos kvinner i løpet av de siste 20 årene (23). En forklaring kan være at en høyere andel av kvinnene enn mennene som hadde urinsyregikt rapporterer hypertensjon, nyresvikt og bruk av vanndrivende legemidler (26-28). Imidlertid rapporterer flere menn enn kvinner et høyere alkoholforbruk av øl, en viktig årsaksfaktor hos denne gruppen (26-28).

\section{Rase/befolkningsgruppe}

I en studie av medisinstudenter, 352 svarte menn i Meharry Cohort studien og 571 hvite menn i Johns Hopkins Precursor studien, var relativ risk (RR) for urinsyregikt hos svarte menn 1,69 (95\% CI 1,02-2,80) sammenlignet med hvite menn (29). Dette ble forklart med en høyere risiko for hypertensjon blant de svarte. Betydningen av den genetiske komponenten for forekomsten av urinsyregikt er vist $\mathrm{i}$ ulike studier av befolkningsgrupper som aboriginere i Taiwan. Prevalensen av hyperurikemi og urinsyregikt i denne befolkningsgruppen er vesentlig høyere med en andel på henholdsvis $53,8 \%$ og $26,6 \%$ blant mennene. Prevalensen for urinsyregikt blant maorimenn i New Zealand er $13,9 \%$, en prevalens som er 3 ganger høyere enn for europeiske ættede menn (30,31). Disse forekomstene er klart høyere enn forekomsten i de amerikanske og nordiske studiene. Det var ingen signifikant forskjell i forekomst av hypertensjon og økt kroppsmasseindeks (KMI) hos aboriginere med og uten urinsyregikt. Alkohol var en underordnet faktor i utviklingen av hyperurikemi siden hyperurikemien allerede forelå før 20 års alderen.

\section{Modifiserbare risikofaktorer}

\section{Serumurinsyre og urinsyregikt}

I Normative Aging studien ble insidensen av urinsyregikt stratifisert etter tidligere urinsyrenivå (32). Basert på 84 insidente tilfeller over en 15 års periode fant man at den årlige insidensen av urinsyregikt hos menn var $0,1 \%$ ved et urinsyrenivå mindre enn 416 mikromol/L, 0,4\% for de med 416-470 mikromol/L, 0,8\% for de med 476-529 mikromol/L, 4,3\% ved 535$589 \mathrm{mikromol} / \mathrm{L}$ og mer enn $7,0 \%$ ved verdier høyere enn $595 \mathrm{mikromol} / \mathrm{L}$.

En kinesisk populasjonsstudie som fulgte menn med hyperurikemi gjennom en 5 års periode, fant 42 insidente tilfeller (33). Årlig insidensrate for urinsyregikt var 2,2\% ved en serumkonsentrasjon på 416-470
mikromol/L, 5,5\% for 476-529 mikromol/L og 12,2\% for urinsyrenivå høyere eller lik $535 \mathrm{mikromol} / \mathrm{L}$. Det fins ikke data for urinsyrenivåets innvirkning på insidensen av urinsyregikt hos kvinner. I den kinesiske studien fant man hos menn en signifikant assosiasjon mellom fedme, alkoholforbruk og bruk av vanndrivende legemidler uavhengig av urinsyrenivået (33). Det ble funnet en signifikant interaksjon mellom persisterende alkoholbruk og forhøyet urinsyrenivå. Visse risikofaktorer er mer assosiert til menn som har hyperurikemi. Fordi nyrens utskilling av urinsyre er nedsatt hos de som har hyperurikemi (som ved urinsyregikt), kan absorpsjonen av puriner i maten forårsake en høyere stigning i blodets urinsyrenivå enn hos de som har normourikemi.

\section{Fedme}

Johns Hopkins Precursor studien viste at økt kroppsmasseindeks (KMI) ved 35 års alder, men ikke ved 22 års alder, var assosiert med risiko for urinsyregikt (RR 1,12 med 1 enhetsøkning i KMI, $p=0,02$ ). Den Normative Aging studien viste at KMI ved start (gjennomsnittsalder 52 år) var signifikant assosiert med hyperurikemi eller urinsyregikt (32). Framinghamstudien viste en signifikant høyere KMI hos pasienter som hadde urinsyregikt etter justering for alder (34).

I Health Professionals Follow-Up studien (HPFS) ble det funnet en assosiasjon mellom KMI og insident urinsyregikt (35). Sammenlignet med KMI fra 21 til $22,9 \mathrm{~kg} / \mathrm{m}^{2}$ hadde menn med en KMI på $25-29,9 \mathrm{~kg} / \mathrm{m}^{2}$ en multivariat RR for urinsyregikt på 1,95 (1,44-2,65), ved KMI 30-34,9 kg/m ${ }^{2}$ en RR 2,33 (1,62-3,36), og ved KMI høyere enn $35 \mathrm{~kg} / \mathrm{m}^{2}$ en RR 2,97 (1,73-5,10) ( $\mathrm{P}$ for trend $<0,001)$. Økning eller reduksjon i vekt hadde også en tydelig effekt på RR. Vektøkning kan føre til hyperurikemi og redusert utskilling av urinsyre gjennom nyrene (36).

\section{Kosthold}

Purinrik kost og høyt proteininntak har lenge vært antatt å være risikofaktorer for utvikling av urinsyregikt (36). I Health Professionals Follow-Up studien (HPFS) ble matinntak og risiko for insident urinsyregikt over en 12 års periode vurdert hos 47150 mannlige deltakere. 730 insidente tilfeller av urinsyregikt ble prospektivt registrert (25). Menn i den høyeste kvintilen av kjøtt- og sjømatinntak hadde henholdvis $41 \%$ og $51 \%$ høyere risiko for urinsyregikt enn menn i den laveste kvintilen. Purinrik vegetarkost økte ikke risikoen for urinsyregikt, men menn i den høyeste kvintilen av vegetarprotein og meieriprodukter hadde henholdsvis $27 \%$ og $48 \%$ lavere risiko for å utvikle urinsyregikt sammenlignet med de som hadde lavest inntak. Omega-3 fettsyrer øker ikke risikoen for urinsyregikt (37). Det er laget en helsekostpyramide med kostanbefalinger som viser innvirkning på risikoen for urinsyregikt (Figur 1) (37).

\section{Alkohol}

Assosiasjonen mellom alkoholinntak og risikoen for urinsyregikt har vært mistenkt i mange år. I HPFS- 


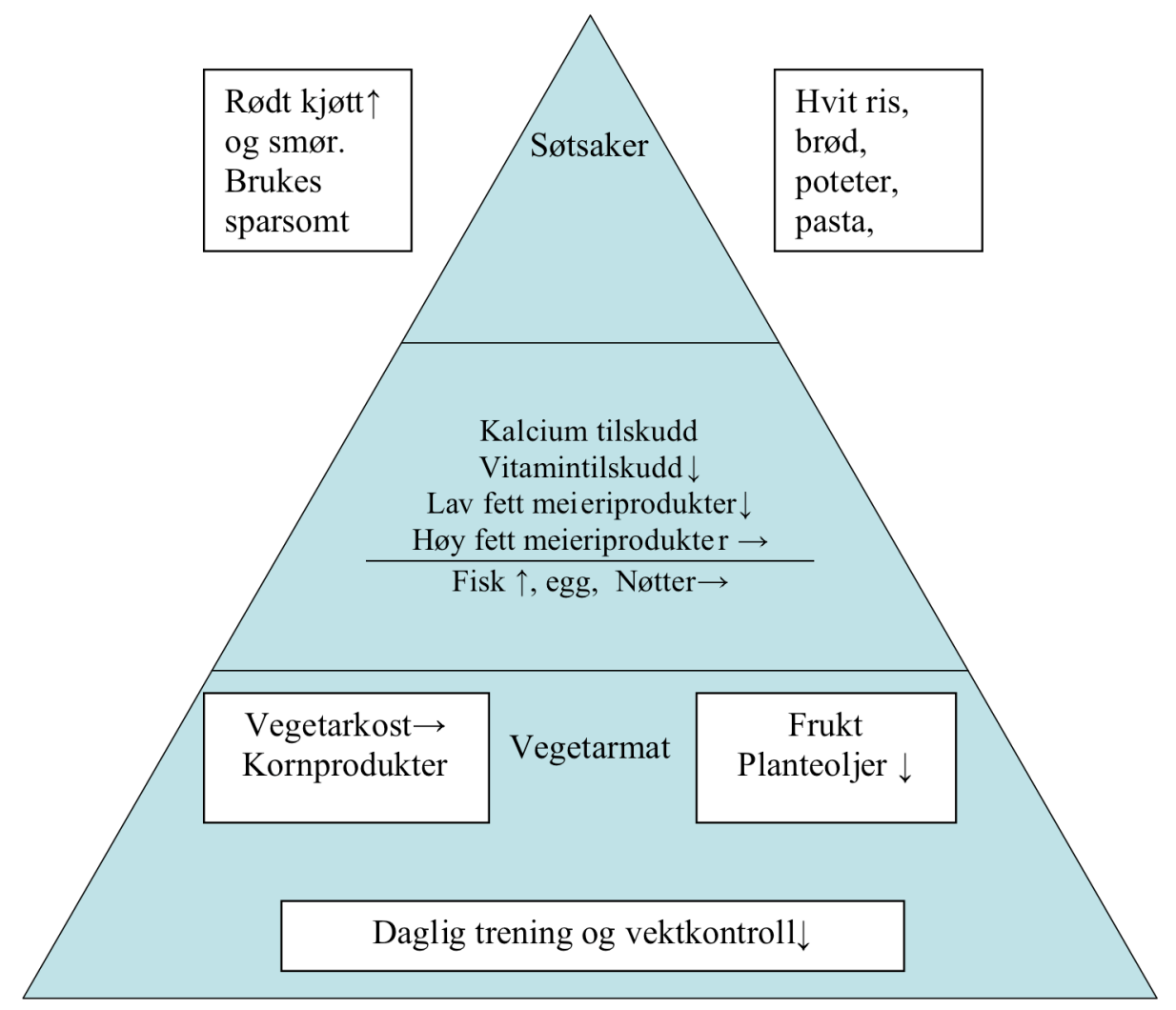

Figur 1. Helsekostpyramiden. Modifisert til norsk etter referanse 37. Helsekostpyramiden viser hvordan ulike produkter virker inn på risikoen for å utvikle urinsyregikt. $\uparrow ø k$ et risiko, $\downarrow$ redusert risiko, $\rightarrow$ uten betydning.

studien ble risikoen i multivariat analyse for utvikling av urinsyregikt sammenlignet mellom ikke alkoholbruk og ulike mengder alkoholinntak. RR 1,25 (95\% CI 0,95-1,64) ved alkoholinntak av 5-9,9 g pr dag, RR 2,53 (95\% CI 1,73-3,70) ved alkoholinntak $\geq 50 \mathrm{~g} \mathrm{pr}$ dag ( $\mathrm{P}$ for trend $<0,001)$ (38). Øl ga høyest risiko for urinsyregikt og høyere enn brennevin, mens moderat vininntak ikke økte risikoen. Forskjellen forklares med ølets høye purinnivå (39).

\section{Medikamenter og noeringstilskudd}

I HPFS-studien med 12 års oppfølging av menn som tidligere ikke hadde hatt urinsyregikt, var vanndrivende legemidler uavhengig assosiert med økt risiko for insident urinsyregikt med RR 1,77 (95\% CI 1,42$2,20)$. Økningen var uavhengig av om det forelå hypertensjon (35). Fordi indikasjonene for behandlingen i seg selv kan øke risikoen for urinsyregikt er det viktig med justering for dette $\mathrm{i}$ analysen. Flere av medikamentene som brukes $i$ behandlingen av samtidig foreliggende andre sykdommer, kan påvirke utskillingen av urinsyre via nyrene. Salicylater i lav dose og ciclosporin reduserer utskillelsen, mens losarten øker den (40).

Vitamin $\mathrm{C}$ har en urikosurisk effekt. Inntak av $4 \mathrm{~g}$ askorbinsyre fører til en dobling $i$ den fraksjonerte utskillelsen av urinsyre opptil 6 timer etter inntak, og inntak av 8 g i 2-3 dager fører til redusert urinsyrenivå på $184 \mathrm{mikromol} / \mathrm{L}$ pga. vedvarende urikosuri (41). I en nylig studie av daglig inntak av $500 \mathrm{mg}$ vitamin C førte dette til en reduksjon i serum urinsyrenivå på 30 mikromol/L (42).

\section{Urinsyregikt og assosiasjon med andre tilstander}

I HPFS-studien er hypertensjon og nyresvikt uavhengig assosiert med insident urinsyregikt, henholdsvis RR 2,31 (95\% CI 1,96-2,72) og RR 4,60 (95\% CI 1,88-11,25) (35). Diagnosen urinsyregikt øker risikoen for nyrestein (RR 2,12; 95\% CI 1,22-3,68). I Framingham-studien var urinsyregikt assosiert med en $60 \%$ økning av risikoen for hjerte/karsykdom (28).

Urinsyregiktpasienter i England har en høyere risiko for koronarsykdom (OR 1,75; 95\% CI 1,7-1,8), hypertensjon (OR 1,5; 95\% CI 1,5-1,6) og kronisk nyresvikt (OR 5,0; 95\% CI 4,3-5,7) (43). Økningen i frekvensen av urinsyregikt må sees i sammenheng med økningen av fedme og metabolsk syndrom, begge kjente kraftfulle kardiovaskulære risikofaktorer (44).

Noen studier har antydet at hyperurikemi kan være en uavhengig risikofaktor for hjerte-karsykdom, mens andre studier tolker en slik sammenheng mer forsiktig. Forskjellen kan også skyldes umålte konfoundere og publikasjonsbias (45).

I nye data fra HPFS-studien med 51000 menn som ble fulgt over en 12 års periode ble det registrert 5800 dødsfall hvorav 2100 døde på grunn av kardiovaskulære sykdommer (45). I forhold til menn uten 
urinsyregikt og uten koronarsykdom var den relative risikoen for død hos dem som hadde urinsyregikt 1,3, den relative risiko for kardiovaskulær død var 1,4 og for koronar død 1,6 (46).

\section{KONKLUSJON}

Urinsyregikt forekommer hyppigere hos menn enn hos kvinner. Etter menopausen blir forskjellen stadig mindre. Insidensen er lav hos unge voksne, men øker med alderen. Spesielt stor er økningen etter 50 års alder. Risikoen for akutte anfall er knyttet til urinsyrenivået $\mathrm{i}$ blodet. De siste tiårene er insidens og prevalens økende, trolig som en følge av overvekt og livsstilssykdommer som hypertensjon, metabolsk syndrom, diabetes og hjerte-karsykdom. Økt bruk av legemidler som har ugunstig innvirkning på urinsyrenivået bidrar også. Legemidler er viktig i den akutte behandlingen, men for å forebygge akutte anfall må livstilsendringer og kosthold ha en fremtredende plass. Forhøyet urinsyre uten anfall av urinsyregikt regnes som en risikofaktor for utvikling av hjerte-karsykdom, men det er ennå uklart om den kan regnes som en selvstendig bidragsyter eller bare en markør til sykeligheten og dødeligheten.

\section{REFERANSER}

1. Terkeltaub RA. Clinical practice. Gout. N Engl J Med 2003; 349: 1647-55.

2. Choi H. Epidemiology of crystal arthropathy. Rheum Dis N Am 2006; 32: 255-73.

3. Wallace SL, Robinson H, Masi AT et al. Preliminary criteria for the classification of the acute arthritis of primary gout. Arthritis Rheum 1977; 20: 895-900.

4. Criteria CIOMS. Rome. Appendix 1. Proposed diagnostic criteria for use in population studies. In: Kellgren JH, Jeffrey MR, Ball J, eds. The epidemiology of chronic rheumatism. Oxford: Blackwell, 1963: 324-6.

5. Bennett PH, Wood PHN, eds. Population studies of the rheumatic diseases. Proceedings of the $3^{\text {rd }}$ International Symposium, New York, June 5-10, 1966. Amsterdam: Excerpta Medica, 1968: 457-8.

6. Schaffalitzky de Muckadell OB, Gyntelberg F. Occurrence of gout in Copenhagen males aged 40-59. Int J Epidemiol 1976; 5: 153-8.

7. Mikkelsen WM, Dodge HJ, Duff IF et al. Estimates of the prevalence of rheumatic diseases in the population of Tecumseh, Michigan, 1959-60. J Chron Dis 1967; 20: 351-69.

8. Thorpe JJ, Daley JM. Hyperucemia and gout in an employee population. J Occup Med 1971; $13: 524$.

9. Bergstrøm G, Bjelle A, Sorensen LB et al. Prevalence of rheumatoid arthritis, osteoarthritis, chondrocalcinosis and gouty arthritis at age 79. J Rheumatol 1986; 13: 527-34.

10. Bengtsson C, Tibblin E. Serum uric acid in women. An epidemiological survey with special reference to women with high serum uric acid level. Acta Med Scand 1976; 196: 93-102.

11. Hedstrand H, Åberg H. Detection and characterisation of middle-aged men with hypertension. Acta Med Scand 1976; 199: 273-78.

12. Aarflot T, Laerum E, Bruusgaard D. Uric acid and chronic musculocomplaints. Scand J Rheumatol 1992; 21: 277-82.

13. Lawrence RC, Helmick CG, Arnett FC et al. Estimates of the prevalence of arthritis and selected musculoskeletal disoroders in the United States. Arthritis Rheum 1998; 41: 778-99.

14. Hall AP, Barry PE, Dawber TR et al. Epidemiology of gout and hyperuricemia. A long-term population study. Am J Med 1967; 42: 27-37.

15. O'Sullivan JB. Gout in a New England town. A prevalence study in Sudbury, Massachusetts. Ann Rheum Dis 1972; 31: 166-9.

16. Kramer HM, Curhan G. The association between gout and nephrolithiasis: the National Health and Nutrition Examination Survey III, 1988-1994. Am J Kidney Dis 2002; 40: 37-42.

17. Roubenhoff R. Gout and hyperuricemia. Rheum Dis Clin North Am 1990; 16: 539-50.

18. Centers for Disease Control and Prevention. National Centre for Health Statistics. Vital and health statistics: current estimates from the National Health Inetrview Survey, 1996. Series 10. No 200. Atlanta: Department of Health and Human Services (US). Available at: http: //www.cdc.gov/nchs/data/series/sr_10/sr10_200.pdf.

19. Lawrence RC, Hochberg MC, Kelsey JL et al. Estimates of the prevalence of selected arthritic and musculoskeletal diseases in the United States. J Rheumatol 1989; 16: 427-41.

20. Harris CM, Lloyd DC, Lewis J. The prevalence and prophylaxis of gout in England. J Clin Epidemiol 1995; 48: $1153-8$.

21. Wallace KL, Reidel AA, Joseph-Ridge $\mathrm{N}$ et al. Increasing prevalence of gout and hyperuricemia over 10 years among older adults in managed care population. $J$ Rheumatol 2004; 31: 1582-7.

22. Isomäki H, v Essen R, Ruutsalo HM. Gout, particularly diuretic induced, is on the increase in Finland. Scand J Rheumatol 1977; 6: 213-6. 
23. Armodee E, Michet CJ, Crowson CS et al. Epidemiology of gout: is the incidence rising? J Rheumatol 2002; 29: 2403-6.

24. Roubenhoff R, Klag MJ, Mead LA et al. Incidence and risk factors for gout in white men. JAMA 1991; 266: 3004-7.

25. Choi HK, Atkinson K, Karlson EW et al. Purine-rich foods, dairy and protein intake, and the risk of gout in men. N Engl J Med 2004; 350: 1093-103.

26. Lally EV, Ho Jr G, Kaplan SR. The clinical spectrum of gouty arthritis in women. Arch Intern Med 1986; 146: 2221-5.

27. Puig JG, Michan AD, Jiminez ML et al. Female gout, clinical spectrum and uric acid metabolism. Arch Intern Med 1991; 151: 726-32.

28. Macfarlane DG, Dieppe PA. Diuretic-induced gout in elderly women. Br J Rheumatol 1985; 24: 155-7.

29. Hochberg MC, Thomas J, Thomas DJ et al. Racial differences in the incidence of gout. The role of hypertension. Arthritis Rheum 1995; 38: 628-32.

30. Chou CT, Lai JS. The epidemiology of hyperuricemia and gout in Taiwan Aborigines. Br J Rheumatol 1998; 37: 258-62.

31. Klemp P, Stansfield SA, Castle B, Robertson MC. Gout is on the increase in New Zealand. Ann Rheum Dis 1997; 56: 22-26.

32. Campion EW, Glynn RJ, DeLabry LO. Asymptomatic hyperuricemia. Risks and consequences in the Normative Aging Study. Am J Med 1987; 82: 421-6.

33. Lin KC, Lin HY, Chou P. The interaction between uric acid level and other risk factors on the development of gout among asymptomatic hyperuricemic men in a prospective study. J Rheumatol 2000; 27: 1501-5.

34. Abbot RD, Brand FN, Kannel WB et al. Gout and coronary heart disease: the Framingham Study. J Clin Epidemiol 1988; 41: 237-42.

35. Choi HK, Atkinson K, Karlson EW et al. Obesity, weight change, hypertension, diuretic use, and risk of gout in men - The Health Professionals Follow-Up study. Arch Intern Med 2005; 165: 742-8.

36. Fam AG. Gout, diet, and the insulin resistance syndrome. J Rheumatol 2002; 29: 1350-5.

37. Choi HK, Mount DB, Reginato AM. Pathogenesis of gout. Ann Intern Med 2005; 143: 499-516.

38. Choi HK, Atkinson K, Karslon EW et al. Alcohol intake and risk of incident gout in men - a prospective study. Lancet 2004; 363: 1277-81.

39. Gibson T, Rodgers AV, Simmonds HA et al. Beer drinking and its effect on uric acid. Br J Rheumatol 1984; 23: 203-9.

40. Caspi D, Lubart E, Graff E et al. The effect of mini-dose aspirin on renal function and uric acid handling in elderly patients. Arthritis Rheum 2000; 43: 103-8.

41. Stein HB, Hasan A, Fox IH. Ascorbic acid-induced uricosuria. A consequency of megavitamin therapy. Ann Intern Med 1976; 84: 385-8.

42. Huang HY, Appel LJ, Choi MJ et al. The effects of vitamin C supplementation on serum concentrations of uric acid: results of a randomized controlled trial. Arthrtis Rheum 2005; 52: 1843-7.

43. Mikuls T, Farrar J, Bilker W et al. Gout epidemiology: results from the UK General Practice Research Database, 1990-1999. Ann Rheum Dis 2005; 64: 267-72.

44. Johnson R, Rideout B, Uric acid and diet: insights in the epidemic of cardiovascular disease. $N$ Engl J Med 2004; 350: 1071-73.

45. Baker J, Krishnan E, Chen L, Schumacher H. Serum uric acid and cardiovascular disease: recent developments, and where do they leave us? Am J Med 2005; 118: 816-26.

46. Choi HK, Curhan G. Independent impact of gout on mortality and risk for coronary heart disease. Circulation 2007; 116: 894-900. 